\title{
Natural selection causes microscale allozyme diversity in wild barley and a lichen at 'Evolution Canyon', Mt. Carmel, Israel
}

\author{
EVIATAR NEVO*†, IRIS APELBAUM-ELKAHER $\dagger$, JACOB GARTY \& \& AVIGDOR \\ BEILES + \\ $\dagger$ Institute of Evolution, University of Haifa, Mt. Carmel, Haifa 31905 and $\ddagger$ Department of Botany, Tel-Aviv University, \\ Ramat-Aviv, Israel
}

\begin{abstract}
Allozymic diversity was studied for proteins encoded by 28 putative loci in 170 plants of wild barley, Hordeum spontaneum, and for 13 loci in 78 different thalli of the lichen Caloplaca aurantia, from the Lower Nahal Oren microsite, Mt. Carmel, Israel, designated by us 'Evolution Canyon'. The samples of wild barley were collected from six stations: three (upper, middle, lower) on the south-facing slope (SF-slope) and three (lower, middle, upper) on the north-facing slope (NF-slope). The samples of $C$. aurantia were collected from three stations: two (middle and upper) on the SF-slope and one (upper) on the NF-slope. Higher solar radiation on the SF- than on the NF-slope makes it warmer, drier, spatiotemporally more heterogeneous, and climatically more fluctuating and stressful. Consequently, it exhibits an open park forest representing an 'African' savanna landscape. Significant inter- and intraslope allozymic differentiation was found in both organisms with generally higher polymorphism, heterozygosity, allele and gene diversity on the more variable and stressful upper station of the SF-slope, as expected by the niche-width variation hypothesis, and the environmental theory of genetic diversity. Solar radiation, temperature and aridity stress caused interslope and intraslope differences on the SF-slope in genotypes and phenotypes of wild barley and the lichen at the 'Evolution Canyon' microsite, as was the case for beetles, diplopods and earthworms tested at the site. Diversifying natural (microclimatic) selection appears to be the major evolutionary driving force causing interslope and SF-intraslope adaptative genetic divergence. 'Evolution Canyon' proves an optimal model for unravelling evolution in action, across life and organizational levels.
\end{abstract}

Keywords: genetic diversity, Hordeum spontaneum, lichens, microgeographical variation, selection, wild barley.

\section{Introduction}

Natural selection has been the central mechanism of Darwinian evolution (Darwin, 1859), yet its quantification in nature at both macro- and microscales of genotypes and phenotypes remains largely problematic (e.g. Endler, 1986). Particularly at the genotypic level, the evolutionary forces driving evolution, whether neutral (Kimura, 1983), near-neutral (Ohta \& Tachida, 1990) or selective (Nevo, 1988) remain controversial. Critical tests at both the single and multilocus levels of proteins and DNA are needed to highlight the relative importance of nonselective

\footnotetext{
${ }^{*}$ Correspondence. E-mail: e.nevo@uvm.haifa.ac.il
}

and selective factors in evolution. Our long-term research programme of genetic diversity in natural populations (Nevo, 1978, 1988, 1990; Nevo et al., 1984) focuses at present at the 'Evolution Canyon' microsite (Nevo, 1994, 1995) attempting to shed some more light on this and other unresolved problems of evolutionary biology.

'Evolution Canyon' at Lower Nahal Oren, Mt. Carmel, Israel $\left(32^{\circ} 43^{\prime} \mathrm{N}, 34^{\circ} 58^{\prime} \mathrm{E}\right)$ is a Plio-Pleistocene erosion gorge cut in Cenomanian limestones in a Mediterranean ecosystem. It provides an excellent model for studying evolution in action. As elsewhere north of the equator (Shreve, 1922; Cottle, 1932), its south-facing slope (hereafter SF-slope) receives higher solar radiation, here up to 300 per cent 
higher than the opposite north-facing slope (hereafter NF-slope), separated by only a few hundred metres. Thus, despite the interslope shared geology and macroclimate, the opposite slopes display dramatic biotic divergence caused by microclimatic differences. The SF-slope represents an open park forest of Ceratonia siliqua, Pistacia lentiscus and savanna grassland, whereas the NF-slope displays a lush dense and green maquis of Quercus caliprinos and Pistacia palaestina. The opposite SF and NF slopes exhibit, respectively, an 'African-Asian' vs. a 'South European' biota (fig. 1 in Nevo, 1995), in a Mediterranean background. The SF-slope is richer in terrestrial species, both plants and animals, whereas the NF-slope is richer in aquatic-dependent taxa such as cryptogamic plants and fungi (Nevo, 1995). In a series of studies we tested the structure and level of multilocus allozyme organization in an attempt to test natural selection at the microsite. According to the niche-width variation hypothesis (Van Valen, 1965), and the environmental theory of genetic diversity (Soulé \& Stewart, 1970; Nevo, 1988), genetic polymorphism is expected to be higher in a wide, heterogeneous (Levene, 1953) and more stressful (Nevo, 1988, 1995; Hoffmann \& Parsons, 1991) ecological niche. At 'Evolution Canyon' the SF-slope is ecologically more heterogeneous and stressful in space and over time. Accordingly, natural selection is expected to generate and maintain higher genetic polymorphism on the SF-slope. Here we tested multilocus organization in a lichen and wild barley, i.e. in lower and higher plants, supporting the hypothesis of higher genetic polymorphism on the ecologically more vari- able SF-slope. Strong natural selection is the only conceivable force which could generate and maintain higher genetic polymorphism in the subpopulations of wild barley and lichens on the SF-slope, separated only by a few hundred metres from the NF-slope. No mutation, migration, stochastic or neutral model can explain it.

\section{Materials and methods}

Subpopulations of wild barley Hordeum spontaneum (Nevo, 1992) and less extensively the lichen Caloplaca aurantia (Galun, 1970) were sampled at six stations, three on the SF-slope $(1,2,3)$ and three on the NF-slope $(5,6,7)$ (Table 1$)$. We analysed 28 putative gene loci in $H$. spontaneum (Table A; this table, and all others denoted by letters, are obtainable from the authors on request) and 13 putative gene loci in $C$. aurantia (Table $C$ ) by starch gel electrophoresis (Nevo et al., 1979; details and modifications in Apelbaum-Elkaher, 1994). For a list of enzymatic systems and their abbreviation see Table 2 , for $H$. spontaneum and C. aurantia, separately. We estimated allelic polymorphisms $(\mathrm{Po})$, mean number of alleles per locus $(A)$, observed heterozygosity $(H)$, gene diversity $\left(H_{\mathrm{e}}\right)$, interpopulation diversity $\left(F_{\mathrm{ST}}\right)$, inbreeding coefficient $\left(F_{\mathrm{IS}}\right)$, and genetic distance $(D)$, all as defined by Nei $(1972,1978)$. These quantities were analysed using Bıosys-1 (Swofford \& Selander, 1989), and tested by nonparametric tests (Wilcoxon and sign test, Siegel, 1956), or by a parametric test (Student's $t$-test).

In $C$. aurantia protein homogenates were extracted from the entire lichen without identifying

Table 1 Genetic distances ( $D$; Nei, 1978) among the subpopulations of Hordeum spontaneum and Caloplaca aurantia at 'Evolution Canyon', Lower Nahal Oren, Mt. Carmel, Israel

\begin{tabular}{|c|c|c|c|c|c|}
\hline \multirow{2}{*}{$\begin{array}{l}\text { Slope: } \\
\text { Station: }\end{array}$} & \multicolumn{2}{|c|}{ SF } & \multicolumn{3}{|c|}{ NF } \\
\hline & $\begin{array}{l}\text { Middle } \\
2\end{array}$ & $\begin{array}{c}\text { Low } \\
3\end{array}$ & $\begin{array}{c}\text { Low } \\
5\end{array}$ & $\begin{array}{c}\text { Middle } \\
6\end{array}$ & $\begin{array}{c}\text { High } \\
7\end{array}$ \\
\hline \multicolumn{6}{|c|}{ Hordeum spontaneum } \\
\hline SF 1 & 0.113 & 0.098 & 0.042 & 0.046 & 0.050 \\
\hline SF 2 & - & 0.005 & 0.035 & 0.057 & 0.070 \\
\hline SF 3 & - & - & 0.027 & 0.054 & 0.068 \\
\hline NF 5 & - & - & - & 0.018 & 0.019 \\
\hline NF 6 & - & 一 & - & - & 0.012 \\
\hline \multicolumn{6}{|c|}{ Caloplaca aurantia } \\
\hline SF 1 & 0.0065 & & & & 0.057 \\
\hline SF 2 & - & & & & 0.056 \\
\hline
\end{tabular}

$\mathrm{SF}$, south facing; NF, north facing. 
those originating from the symbiotic fungus or alga, or from their interaction. We assume, however, that allozymic variation is primarily that of the fungus, because: (i) the latter forms most of the thallus (Mattsson \& Karnefelt, 1986); (ii) nine out of the 11 enzymes tested displayed a one-locus multiple allelic isozyme, presumably representing one organism; only two isozymes Pgi and Pgm exhibited two multiple allelic isozymes which may belong only to the fungus; (iii) in eight out of the 13 genetic loci tested only two bands were detected that are explainable as Mendelian alleles of the same system. Detailed electrophoretic and statistical techniques appear in Apelbaum-Elkaher (1994).

\section{Results}

\section{Genetic diversity in $\mathrm{H}$. spontaneum}

Twenty out of the 28 loci ( 71.4 per cent) tested in $H$. spontaneum were polymorphic, whereas eight loci were monomorphic (Adh-1, $A d h-2, G d h-1$, Aat-2, Aat-3, 6Pgd-1, Mdh-1 and Pgm). Including the monomorphic loci, we found 64 different alleles altogether, 58 on the SF-slope and 53 on the NF-slope (allele frequencies given in Table A). Eleven unique alleles were found on the SF-slope, four of which were rare $(0.036-0.045)$ and seven common (0.053-0.111). Six alleles were unique to the NF-slope, one rare $(0.042)$ and five common $(0.050-0.316)$. The rare alleles varied within slopes. On the SF-slope, seven unique alleles (74 per cent) occurred only at the upper station, two only at the middle station (18 per cent) and two ranged at both stations 1 and 2 (18 per cent). The lowest station (no. 3) had no unique alleles. By contrast, on the NF-slope two unique alleles (33.3 per cent) occurred only at the upper station (no. 7); two other unique alleles ( 33.3 per cent) occurred only at the lower station (no. 5), and the remaining two alleles ranged across the entire slope (Table B, obtainable from the authors).

\section{Interslope genetic diversity differences}

A significant interslope difference was found in the frequencies of nine loci: Est-2,4,5, G6pd-2, $M d h-2$, Nadh-1, Pepc, Pept-2 and Pgi-2 (Table A). The genotype counts have been used for the $\chi^{2}$ and Fisher exact tests, instead of the allele counts, because of the high homozygosity of wild barley.

The $F_{\mathrm{ST}}$ values (which measure the relative genetic diversity between subpopulations, Wright, 1965) of the 20 polymorphic loci appear in Table A.
They can be regarded as parallel to the values for the genetic distance $D(\mathrm{Nei}, 1973,1978)$ between the subpopulations which are presented in Table 1 . The smallest $D$ was between stations $2-3$ and 6-7 (0.005 and 0.012 , respectively). The largest $D$ was between stations 1 and 2 or 3 . Station 1 on the SF-slope is closer genetically to the three stations on the NF-slope than to the two stations ( 2 and 3 ) on the same slope.

The $F_{\mathrm{ST}}$ estimates are distributed discontinuously. The $F_{\mathrm{ST}}$ of three loci (Nadh-1, Est-4 and Est-5) showed high divergence ( $F_{\mathrm{ST}}$ between 0.087 and 0.222 ). Four loci showed intermediate interslope divergence: $M d h-2, P g i-2, E s t-2$ and Pepc $\left(F_{\mathrm{ST}}\right.$, $0.040-0.051)$. Six loci showed low interslope divergence: Hk-2, Pept-2, Gdh-2, Hk-1, Sod-2 and G6pd-2 (0.011 to 0.021$)$. Three loci showed very low interslope divergence: Sod-1, G6pd-1 and Ipo (0.006-0.007) and finally four loci (Nadh-2, Pept-1, $6 P g d-1$ and $A c p h-2$ ) showed no interslope divergence at all: $F_{\mathrm{ST}}=0.001$ (Table A).

\section{Interslope and intraslope genetic diversity}

The highest levels of genetic diversity were observed at the highest station (no. 1) on the SF-slope in the $H$ diversity measure of the lichen and in all four such measures of wild barley. We found statistically higher genetic diversity on the upper station of the SF-slope than on the other stations in wild barley: single locus $H_{\mathrm{e}}$ was highest at station 1 in seven out of 20 loci (binomial test, $P=0.037$ ) (Tables 2 and A). Polymorphism increased clinally from the lower station (no. 3) on the SF-slope upwards to station 1. $H$ and $A$ were also highest at station 1 and heterozygotes were found only on the SF-slope.

\section{Genetic differentiation at the two-locus level in Hordeum spontaneum}

Gametic phase disequilibria (D) of $H$. spontaneum for each slope are given in Tables 3 and D. The D's are classified into general (occurring on both slopes) and specific related either to the SF- or NF-slope. Examples of general D's were: $P e p c^{h}-P e p t-I^{b}$ $\left(\mathrm{D}=0.056^{* * *}, 0.054^{* * *}\right.$ on the NF- and SF-slopes, respectively); Hk-1 $1^{b}-P e p c^{b} \quad\left(\mathrm{D}=0.094^{(i)}, 0.048^{*}\right.$, respectively). The meanings of the@sign and the stars are given in Table 3 . D's specific to the NF-slope were for example: $N a d h-2^{b}-$ Pept- $2^{b}$ $\left(\mathrm{D}=-0.063^{* *}\right)$, Est $-2^{b}-$ G6pd $-2^{b} \quad\left(\mathrm{D}=-0.052^{*}\right)$. D's specific to the SF-slope were: $E s t-4^{\text {null }}-E s t-5^{b}$ $\left(\mathrm{D}=0.154^{* * * *}\right), I p o^{h}-N a d h-1^{b} \quad\left(\mathrm{D}=0.123^{* * * *}\right)$. A few disequilibria revealed similar nonsignificant and 
Table 2 Allozyme diversity at 'Evolution Canyon', Lower Nahal Oren, Mt. Carmel, Israel, of Hordeum spontaneum (28 loci), at six stations, three on the south-facing slope (SF-slope) (1-3) and three on the north-facing slope (NF-slope) (5-7), and Caloplaca aurantia (13 loci) at three' stations, two on the SF-slope $(1,2)$ and one on the NF-slope (7). Allozyme diversity was measured by: proportion of polymorphic loci, criterion 5 per cent $(P o)$, mean number of alleles per locus $(A)$, observed heterozygosity $(H)$, and gene diversity $\left(H_{\mathrm{e}}\right)$. Allozymes are listed below

\begin{tabular}{|c|c|c|c|c|c|c|c|c|c|c|c|}
\hline \multirow{3}{*}{$\begin{array}{l}\text { Slope } \\
\text { Station }\end{array}$} & \multicolumn{8}{|c|}{ H. spontaneum } & \multicolumn{3}{|c|}{ C. aurantia } \\
\hline & \multicolumn{3}{|c|}{ SF } & \multicolumn{3}{|c|}{ NF } & \multicolumn{2}{|c|}{ Pooled } & \multicolumn{2}{|c|}{ SF } & \multirow{2}{*}{ 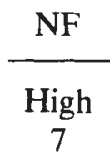 } \\
\hline & $\begin{array}{c}\text { High } \\
1\end{array}$ & $\begin{array}{l}\text { Middle } \\
\quad 2\end{array}$ & $\begin{array}{c}\text { Low } \\
3\end{array}$ & $\begin{array}{c}\text { Low } \\
5\end{array}$ & $\begin{array}{l}\text { Middle } \\
\quad 6\end{array}$ & $\begin{array}{c}\text { High } \\
7\end{array}$ & SF-slope & NF-slope & $\underset{1}{\text { High }}$ & $\begin{array}{l}\text { Middle } \\
\quad 2\end{array}$ & \\
\hline Average $N$ : & 25.5 & 20.6 & 26.5 & 15.8 & 31.6 & 19.2 & 72.7 & 66.6 & 33.3 & 19.5 & 26.5 \\
\hline Po & 0.536 & 0.464 & 0.357 & 0.429 & 0.464 & 0.464 & 0.607 & 0.571 & 0.923 & 0.692 & 0.923 \\
\hline $\begin{array}{l}A \\
\pm \mathrm{SE}\end{array}$ & $\begin{array}{r}1.89 \\
\pm 0.20\end{array}$ & $\begin{array}{r}1.46 \\
\pm 0.10\end{array}$ & $\begin{array}{r}1.57 \\
\pm 0.20\end{array}$ & $\begin{array}{r}1.57 \\
\pm 0.10\end{array}$ & $\begin{array}{r}1.60 \\
\pm 0.10\end{array}$ & $\begin{array}{r}1.64 \\
\pm 0.10\end{array}$ & $\begin{array}{r}2.07 \\
\pm 0.20\end{array}$ & $\begin{array}{r}1.89 \\
\pm 0.20\end{array}$ & $\begin{array}{r}2.23 \\
\pm 0.20\end{array}$ & $\begin{array}{r}2.00 \\
\pm 0.28\end{array}$ & $\begin{array}{r}2.23 \\
\pm 0.20\end{array}$ \\
\hline $\begin{array}{l}H \\
\pm \mathrm{SE}\end{array}$ & $\begin{array}{r}0.003 \\
\pm 0.002\end{array}$ & $\begin{array}{r}0.0 \\
\pm 0.0\end{array}$ & $\begin{array}{r}0.001 \\
\pm 0.000\end{array}$ & $\begin{array}{r}0.0 \\
\pm 0.0\end{array}$ & $\begin{array}{r}0.0 \\
\pm 0.0\end{array}$ & $\begin{array}{r}0.0 \\
\pm 0.0\end{array}$ & $\begin{array}{r}0.001 \\
\pm 0.000\end{array}$ & $\begin{array}{r}0.0 \\
\pm 0.0\end{array}$ & $\begin{aligned} & 0.142 \\
\pm & 0.42\end{aligned}$ & $\begin{aligned} & 0.085 \\
\pm & 0.38\end{aligned}$ & $\begin{aligned} & 0.124 \\
\pm & 0.26\end{aligned}$ \\
\hline $\begin{array}{l}H_{\mathrm{e}} \\
\pm \mathrm{SE} \\
\end{array}$ & $\begin{array}{r}0.181 \\
\pm 0.039 \\
\end{array}$ & $\begin{array}{r}0.093 \\
\pm 0.026 \\
\end{array}$ & $\begin{array}{r}0.106 \\
\pm 0.034 \\
\end{array}$ & $\begin{array}{r}0.158 \\
\pm 0.041 \\
\end{array}$ & $\begin{array}{r}0.147 \\
\pm 0.037 \\
\end{array}$ & $\begin{array}{r}0.169 \\
\pm 0.042 \\
\end{array}$ & $\begin{array}{r}0.166 \\
\pm 0.038 \\
\end{array}$ & $\begin{array}{r}0.166 \\
\pm 0.038\end{array}$ & 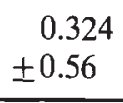 & 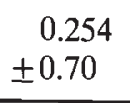 & $\begin{aligned} & 0.327 \\
\pm & 0.57\end{aligned}$ \\
\hline
\end{tabular}

${ }^{1}$ Caloplaca aurantia was sampled at only three stations: 1 (SF-high), 2 (SF-middle) and 7 (NF-high), because only in these stations could enough material be collected for electrophoresis.

List of the loci used for H. spontaneum: Aat = aspartate transminases (EC 2.6.1.1), two loci; $A c p h=$ acid phosphatase (EC 3.1.3.2); $A d h=$ alcohol dehydrogenases (EC 1.1.1.1), two loci; $E s t=$ esterase (EC 3.1.1.2), three loci; $G d h=$ glutamate dehydrogenase (EC 1.4.1.2), two loci; G6pd = glucose-6-phosphate 1-dehydrogenases

(EC 1.1.1.49), two loci; $H k=$ hexokinases (EC 2.7.1.1), two loci; $I p o=$ indophenol oxidase (EC 1.10.3.1); $M d h=$ malate dehydrogenases (EC 1.1.1.37), two loci; $\mathrm{Nadh}=$ lipoamide diaphorases (EC 1.8.1.4), two loci; Pepc = phosphoenolpyruvate carboxylase (EC 4.1.1.31); Pept $=$ peptidases (EC 3.4.13.11 now included in 3.4.13.18 or 19), two loci; Pgi $=$ glucose6-phosphate isomerases (EC 5.3.1.9); Pgm = phosphoglucomutase (EC 2.7.5.1 now 5.4.2.2); 6Pgd = 6-phosphogluconate dehydrogenase (EC 1.1.1.44), two loci; Sod = superoxide dismutases (EC 1.15.1.1), two loci.

List of the loci used for $C$. aurantia: $A a t=$ aspartate transminase (EC 2.6.1.1); Alp = leucyl aminopeptidase (EC 3.4.11.1); $C a t=$ catalase $($ EC 1.11.1.6); Est $=$ esterase (EC 3.1.1.2); $G d h=$ glutamate dehydrogenase (EC 1.4.1.2); G6pd = glucose6-phosphate 1-dehydrogenase (EC 1.1.1.49); Pept = peptidase (EC 3.4.13.11 now included in 3.4.13.18 or 19); $P g i=$ glucose-6-phosphate isomerase (EC 5.3.1.9), two loci; Pgm = phosphoglucomutase (EC 2.7.5.1 now 5.4.2.2), two loci; $6 \mathrm{Pgd}=6$-phosphogluconate dehydrogenase (EC 1.1.1.44); Sod = superoxide dismutase (EC 1.15.1.1).

significant trends on both slopes. Larger samples are needed for substantiating their general or specific classifications. It is obvious from Tables $D$ and 3 that many more disequilibria are specific to the SF-slope. Notably, some D's, e.g. $H k-I^{b}-I p o^{b}$ have different allele associations on the opposite slopes: their D's differ in sign. These displayed extreme divergence.

\section{Multilocus organization}

The multilocus organization index, related to the single-locus Simpson index, and based on the observed distribution of the number of heterozygous loci $(K)$ in two randomly chosen gametes, was proposed by Brown et al. (1980). It measures multilocus associations when multiple alleles and many loci are analysed, combining all paired-loci gameticphase disequilibria. We calculated multilocus organization indices for the SF- and NF-slopes (Table 4). The differences between the expected and observed variances $\left(s_{K}^{2}\right)$ are significant for the SF-slope but nonsignificant for the NF-slope. Multilocus organization appeared to be significantly higher for the SF-slope than for the NF-slope. The standardized index of intensity of multilocus structure $X(2)$ was 1.4 and 0.2 for the SF-slope and NF-slope, respectively. We conclude that multilocus organization is sevenfold higher for the SF-slope. 
Table 3 Examples of gametic phase disequilibria, absolute (D) and relative ( $\left.D^{\prime}\right)$, between paired allozyme loci of Hordeum spontaneum and Caloplaca aurantia at 'Evolution Canyon', Lower Nahal Oren, Mt. Carmel: (i) general, (ii) specific to NF (north-facing)-slope and (iii) specific to SF (south-facing)-slope. Full table (Table D) can be obtained from the authors upon request

\begin{tabular}{|c|c|c|c|c|c|c|}
\hline \multirow{2}{*}{$\begin{array}{l}\text { Hordeum spontaneum } \\
\text { Locus and allele }\end{array}$} & \multicolumn{3}{|c|}{ NF-slope } & \multicolumn{3}{|c|}{ SF-slope } \\
\hline & $\mathrm{D}$ & $\left(D^{\prime}\right)$ & $P$ & $\mathrm{D}$ & $\left(D^{\prime}\right)$ & $P$ \\
\hline $\begin{array}{l}\text { (i) General disequilibria } \\
\text { 1. Pepc } b-P e p t-1 b\end{array}$ & 0.056 & $(1.0, c)$ & $* * * \mathrm{~F}$ & 0.054 & $(0.757)$ & $* * *$ \\
\hline $\begin{array}{l}\text { (ii) Specific to NF-slope } \\
\text { 1. Nadh-2 b-Pept-2b } \\
\text { 2. Est-2 b-G6pd-2 b }\end{array}$ & $\begin{array}{l}-0.063 \\
-0.052\end{array}$ & $\begin{array}{l}(1.0, c) \\
(1.0, c)\end{array}$ & $\begin{array}{l}{ }^{* *} \mathrm{~F} \\
{ }^{*} \mathrm{~F}\end{array}$ & $\begin{array}{l}-0.006 \\
-0.004\end{array}$ & $\begin{array}{l}(0.139) \\
(0.075)\end{array}$ & $\begin{array}{l}\text { NS } \\
\text { NS }\end{array}$ \\
\hline $\begin{array}{l}\text { (iii) Specific to SF-slope } \\
\text { 1. Est-4 null-Est-5 } b \\
\text { 2. Est-5 b-Ipo } b \\
\text { 3. Ipo } b-\text { Nadh-1 } b \\
\text { 4. Est-2 b-Est-5 b }\end{array}$ & $\begin{array}{r}0.016 \\
0.000 \\
-0.008 \\
-0.006 \\
\end{array}$ & $\begin{array}{l}(1.0, c) \\
(0.0) \\
(0.070) \\
(0.035)\end{array}$ & $\begin{array}{l}\text { NS } \\
\text { NS } \\
\text { NS } \\
\text { NS }\end{array}$ & $\begin{array}{r}0.154 \\
-0.124 \\
0.123 \\
-0.071 \\
\end{array}$ & $\begin{array}{l}(0.757) \\
(0.633) \\
(0.770) \\
(0.522)\end{array}$ & $\begin{array}{l}* * * * \\
* * * * \\
* * * * \\
* * *\end{array}$ \\
\hline Caloplaca aurantia & \multicolumn{3}{|c|}{ NF-slope (Upper station) } & \multicolumn{3}{|c|}{ SF-slope (Upper station) } \\
\hline Locus and allele & $\mathrm{D}$ & $\left(D^{\prime}\right)$ & $P$ & $\mathrm{D}$ & $\left(D^{\prime}\right)$ & $P$ \\
\hline $\begin{array}{l}\text { (i) General disequilibria } \\
\text { 1. Gdh } c-P g m-2 c\end{array}$ & -0.032 & $(0.286)$ & NS & -0.036 & $(1.0, c)$ & $@$ F \\
\hline $\begin{array}{l}\text { (ii) Specific to NF-slope } \\
\text { 1. Est } c-P e p t c \\
\text { 2. Aat c-Pgm-2 } c\end{array}$ & $\begin{array}{r}0.116 \\
-0.061\end{array}$ & $\begin{array}{l}(0.497) \\
(1.0, c)\end{array}$ & $\begin{array}{l}* * * \\
* * * \mathrm{~F}\end{array}$ & $\begin{array}{l}0.040 \\
0.040\end{array}$ & $\begin{array}{l}(0.328) \\
(0.258)\end{array}$ & $\begin{array}{l}\text { NS } \\
\text { NS }\end{array}$ \\
\hline $\begin{array}{l}\text { (iii) Specific to SF-slope } \\
\text { 1. Pgm-1 } c-P g m-2 c \\
\text { 2. Est c-G6pd } c^{1}\end{array}$ & $\begin{array}{l}-0.002 \\
-0.058\end{array}$ & $\begin{array}{l}(0.097) \\
(1.0, \mathrm{c})\end{array}$ & $\begin{array}{l}\text { NS } \\
@ \text { F }\end{array}$ & $\begin{array}{r}-0.048 \\
0.054\end{array}$ & $\begin{array}{l}(1.0, c) \\
(0.491)\end{array}$ & ${ }_{* *}^{* *} \mathrm{~F}$ \\
\hline
\end{tabular}

${ }^{*} P<0.05 ;{ }^{* *} P<0.025 ;{ }^{* * *} P<0.01 ;{ }^{* * *} P<0.001$; $@ P<0.10$; NS, $P>0.10 ; P$ by chi-square, or by Fisher exact test $(\mathrm{F})$.

c, Complete association: one gametic type is missing (Clegg et al., 1976).

${ }^{1}$ Similar but nonsignificant disequilibria. Larger samples are needed for a reliable slope classification.

\section{Genetic diversity and divergence in the lichen Caloplaca aurantia}

Out of 13 putative genetic loci tested, 12 (92 per cent) were polymorphic, more than in $H$. spontaneum (71.4 per cent) (Table $\mathrm{C}$ which can be obtained from the authors upon request). Only Sod was monomorphic. In total, the 13 putative genetic loci comprised 31 alleles, 30 and 29 alleles on the SF- and NF-slopes, respectively. Two alleles were unique to the SF-slope, one (6Pgd $)$ unique to upper station 1 and rare (0.013), and the other $\left(P e p t^{d}\right)$ unique to stations 1 and 2 with frequencies 0.059 and 0.045 , respectively. Allele $E s t^{b}$, frequency 0.250 , was unique to the NF-slope (Table B). Likewise, interslope allele distribution of Cat differed significantly $\left(\chi_{1}^{2}=20.3, P<0.001\right)$. The level of $P o$ was equal in the contrasting stations 1 and 7 , but higher than that of station 2. As in $H$. spontaneum, Po increases upwards on the SF-slope from station 2 to 1. Heterozygosity is highest in station 1 and lowest in 2 (Table 2).

The interslope $F_{\mathrm{ST}}$ differential was higher than the intraslope estimates, unlike the finding for $H$. spontaneum. The $F_{\mathrm{ST}}$ levels of $C$. aurantia were also distributed discontinuously. Two loci showed high interslope divergence: $C a t$ and G6pd $\left(F_{\mathrm{ST}}=0.208\right.$ and 0.161 , respectively). Four loci (Aat, Pgi-1, Pgi-2 and Est) formed an intermediate group (0.053-0.063). Three loci (Alp, Pgm-1 and Pgm-2) 
Table 4 Estimates of multilocus genetic organization of Hordeum spontaneum on two opposite slopes of 'Evolution Canyon' in Lower Nahal Oren, Mt.

Carmel, Israel. SF, south-facing; NF, north-facing

\begin{tabular}{lccccc}
\hline $\begin{array}{l}\text { Slope } \\
\text { facing }\end{array}$ & $\begin{array}{c}\text { Polymorphic } \\
\text { loci }\end{array}$ & $\begin{array}{c}\text { Expected } \\
\text { var of } K\end{array}$ & $\begin{array}{c}\text { Upper limit } \\
\text { of 95\% }\end{array}$ & $\begin{array}{c}\text { Estimate of } \\
\text { var of } K^{1}\end{array}$ & $X(2)^{2}$ \\
\hline SF-slope & 14 & 2.634 & $<4.579$ & 6.409 & $1.43^{*}$ \\
NF-slope & 14 & 2.673 & $<4.649$ & 3.296 & 0.23 \\
\hline
\end{tabular}

${ }^{*} P<0.05$.

${ }^{1} K$, number of heterozygous loci in two randomly chosen gametes.

${ }^{2} X(2)$, measure of multilocus structure.

formed a low interslope divergent group $\left(F_{\mathrm{ST}}=0.017\right.$ or 0.018$)$. Gdh was located between the two groups $(0.033)$. The $F_{\text {ST }}$ values of two loci, Pept $(0.005)$ and 6 Pgd (0.001), showed essentially no interslope divergence (Table $\mathrm{C}$ ). Heterozygote deficiency (positive $F_{1 \mathrm{~s}}$ ) was drastic in 10 out of the 12 polymorphic loci (sign test, $P<0.0005$ ). Pgi- 1 was the only locus in which there was a slight excess of heterozygotes for the two S-slope stations (Table C). The genetic distance $D$ between populations 1 and 2 was $D=0.0065$, whereas the interslope distance was $D=0.0564$ (Table 1).

Allozymic variation of $C$. aurantia paralleled that of $H$. spontaneum in displaying higher values for $H$, observed heterozygosity, at station 1 on the SF-slope, climaxing from middle station 2 to upper station 1. However, unlike the wild barley subpopulations, the lichen subpopulations from the SF-slope were genetically closer to each other than to the subpopulation from the NF-slope.

\section{Genetic differentiation at the two-locus level in Caloplaca aurantia}

Gametic phase disequilibria (D) of $C$. aurantia for the upper station on each slope (stations 1 and 7) are given in Tables 3 and $\mathrm{D}$. As in $H$. spontaneum D's were classified into general (occurring on both slopes) and specific, related either to the SF- or NF-slope. The example of general D was $G d h^{c}$ Pgm-2 ${ }^{c} \quad(\mathrm{D}=-0.032,-0.036$ on the NF- and SF-slopes, respectively). $D$ 's specific to the NF-slope were for example: Est $t^{c} P e p t^{c}\left(\mathrm{D}=0.116^{* * *}\right)$ and Aat $-P g m-2^{c}\left(\mathrm{D}=-0.061^{* * *}\right)$. D's specific to the SF-slope were for example: $P g m-I^{c}-P g m-2^{c}$ $\left(\mathrm{D}=-0.048^{* *}\right)$ and $E s t^{c}-G 6 p d^{c}\left(\mathrm{D}=0.054^{* *}\right)$. In a few cases opposite signs characterized the D's on the opposite slopes, for example, Est $-G 6 p d^{c}(-0.058$

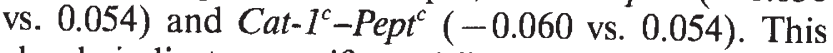
clearly indicates specific multilocus slope selection.

\section{Discussion}

The inter- and intraslope genetic differences displayed by both the wild barley and the lichen in multilocus allozyme polymorphism, heterozygosity, unique alleles and gametic phase disequilibria, can not be explained by mutation, migration, stochastic or neutral models. Mutation is excluded because of its low rates and the many generations needed for the accumulation of differences resulting from mutation pressure without any selective advantage of the mutants. Stochasticity is ruled out because the populations tested are large and their genetic divergence corroborates the theoretical prediction of the nichewidth variation hypothesis with its phenotypic (Van Valen, 1965) and genotypic (Soulé \& Stewart, 1970; Nevo et al., 1984; Nevo, 1988) predictions. The hypothesis predicts a positive correlation of phenotypic and genotypic diversity and niche-width.

The SF-slope is ecologically more spatially and temporally heterogeneous and stressed by drought (seasonally), than its NF-slope counterpart. This is a direct result of the higher solar radiation on the SF. (up to 300 per cent) than on the NF-slope ( $H$. Kutiel \& G. Sher, unpublished data). Furthermore, solar radiation, hence temperature and drought, are highest in station 1, the uppermost station on the SF-slope. Runoff water from stations 1 to 3 and 7 to 5 causes milder and less drought stress in the lower station on both slopes. Polymorphism and allele diversity increased in parallel upwards on the SF-slope in both wild barley and the lichen, towards the highest stress on this slope. Likewise, genetic diversity was generally higher on the more stressed SF- than on the NF-slope. Finally, interslope gametic phase disequilibria in both wild barley (a selfer) and the lichen (a nonselfer) displayed slopemultilocus specificity. This pattern cannot be generated by stochastic processes, and is seemingly explicable only by selection. 
Migration is ruled out as an explanatory model because it equalizes allele frequencies rather than causes interslope divergence. Lack of or low interslope migration may assist interslope divergence caused by another factor. For most organisms, it is hard to assume that no attempts at migration occur across such a small distance. Indeed, interslope migration, which must easily occur among animals (insects and rodents) and through wind transferring seeds and gemmae, must be overridden by diversifying natural selection, which presuambly does not allow the establishment of unfit immigrants on either slope.

The expectation of neutrality, especially in an inbreeder such as wild barley, would predict a random distribution independent of stress, rather than an ecologically determined differential genotype and allele distribution, primarily the existence of the slope-unique alleles and D's despite the geographical proximity. Mutation, stochastic migration and neutral models are unlikely to cause the observed interslope divergence in genetic diversity. By elimination, natural selection appears to be the only major evolutionary driving force able to cause the observed interslope genetic differences. This is particularly true because the results were initially theoretically predicted.

Our $F_{\text {ST }}$ results suggest a low interslope gene flow. These estimates are likely to be even more useful than the rare alleles or maximum likelihood method in supporting a low average gene flow in a subdivided population under a wide variety of conditions (Slatkin \& Barton, 1989). Our $F_{\text {ST }}$ estimates clearly indicate low gene flow. Low gene flow may be caused by large distances, geographical barriers or selection. In view of the local proximity of the slopes, only the last cause is plausible.

At 'Evolution Canyon', as predicted, multilocus genetic (allozymic) diversity was higher in subpopulations on the more stressful SF-slope across phylogeny (review and references in Nevo, 1995), as follows: (i) Buliminus labrosus (land snail); (ii) Pomatias olivieri (land snail); (iii) Tetrathrosoma (Strongylosoma) syriacum (diplopod); (iv) Carabus hemprichi (beetle); (v) Oxythyrea noemi (beetle); (vi) Bimastos syriacus (earthworm); (vii) Hordeum spontaneum (wild barley, this study); (viii) Caloplaca aurantia (lichen, this study). Genetic diversity is higher across phylogeny (i.e. in all seven tested species belonging to six major taxa of plants and animals) on the more heterogenous and stressful 'Asian-African' SF- than on the milder, 'European' NF-slope (sign test, $P=0.016$; fig. 3 in Nevo, 1995). Recently, we increased the number of species tested for genetic diversity on the opposite slopes. Genetic diversity was higher on average on the SF-slope than on the NF-slope in nine out of 11 unrelated taxa (sign test, $P=0.055$; fig. 4 in Nevo, 1997). Likewise, in the two plant species, within-slope genetic diversity on the ecologically spatiotemporally more variable 'Asian-African' SF-slope increases upwards from the lower or middle to the upper station, where stress is maximal. Theoretically, higher genetic diversity is expected in a broader spatiotemporal and/or stressful niche (Van Valen 1965; Soulé \& Stewart, 1970; Nevo et al., 1982, 1984, 1996; Nevo, 1988; Nevo \& Beiles, 1988), as was indeed found here.

'Evolution Canyon' reveals not only genotypic but also phenotypic interslope divergence. This is reflected in biodiversity or species richness across phylogeny from cyanobacteria to lower and higher plants, invertebrates and vertebrates. The SF-slope is richer in taxa of terrestrial species whereas the NF-slope is richer in water- and shade-dependent taxa like cryptogamic plants and fungi. Likewise, interslope adaptive phenotypic morphological, physiological and behavioural patterns abound (Nevo, 1995).

Microgeographical studies elsewhere, in balanids (Nevo et al., 1977), several species of marine organisms (Nevo, 1978; Nevo et al., 1986a), land snails (Nevo et al., 1982), wild barley (Nevo et al., 1981, 1983, 1986b; Olsvig-Whittaker et al., 1992), wild emmer wheat (Golenberg \& Nevo, 1987; Nevo et al., 1988a, b, 1991), Aegilops (Nevo et al., 1994) and also supported the niche-width variation hypothesis when thermal, chemical and climatic differential stresses were tested at the microscale level. In all of these cases, either between or within species, populations exposed to higher ecological variation or stress maintained higher genetic diversity. Our empirical results are consistent with other microscale experimental studies (e.g. Allard et al., 1972; Hamrick \& Allard, 1972; Hamrick \& Holden, 1979; Johannesson et al., 1995). Adaptive phenotypic traits in H. spontaneum at 'Evolution Canyon', have been described for fitness components and germination patterns (Nevo, 1995 and references therein).

Similar results have been obtained in our macrogeographical genetic diversity studies of $H$. spontaneum in Israel, Iran, Turkey and in the synthesis for the entire Near East (reviewed in Nevo, 1992). Both the micro- and macrogeographical results corroborate the theoretical expectation that the existence of a protected polymorphism is more likely in a more heterogeneous environment (e.g. Karlin, 1979, 1981, 1982). Notably, the role of stress in evolution has recently been highlighted (Hoffmann \& Parsons, 
1991; Parsons, 1994). We hypothesize that the interslope genetic patterns observed are affected by diversifying balancing selection on allozyme polymorphisms both at the single- and multilocus levels.

Aridity stress has been previously implicated in allozyme differentiation in many unrelated species in Israel (Nevo \& Beiles, 1988) and elsewhere (Nevo et al., 1984; Nevo, 1995). Higher levels of multilocus genetic allozyme diversity at local (several plant and animal species, Nevo et al., 1982; Golenberg \& Nevo, 1987; Nevo, 1988), regional (in 21 Israeli species; Nevo \& Beiles, 1988) and global levels (1111 species across the planet; Nevo et al., 1984) were shown earlier to be correlated across phylogeny with higher environmental diversity (climatic, chemical, thermal and edaphic) in space and/or time (Nevo, 1988). Similar genetic environmental correlations also occur for nuclear DNA, mitochondrial DNA, DNA fingerprints, polymerase chain reaction (PCR) DNA diversity (Nevo, 1988; Nevo et al., 1996) and DNA sequences (Ugrinovskii et al., 1995). They were also confirmed for several allozyme loci in controlled laboratory experiments of pollution biology (cited in Nevo, 1988).

\section{Conclusions and prospects}

The advantage of 'Evolution Canyon' (though not unique) lies in its sharp interslope physical (microclimatic) and biotic (ecosystem) contrasts despite an interslope shared geology and macroclimate. The single differentiating factor is the interslope difference in solar radiation. Consequently, over a microgeographical scale of several hundred metres global biota representing three continents, Asia, Africa and Europe meet locally, unfolding interslope divergent biota, species richness, genetic diversity and adaptive radiation (Nevo, 1995).

Effective population sizes of most model organisms studied here from the thousands of species at the microsite (fungi, plants and animals) are large, and the interslope distance is minute: hence, presumably stochastic small size population effects are minor evolutionary forces. Likewise, migration can be ruled out as a major evolutionary force, because it cannot generate the observed phenomena and its absence, as indicated by the $F_{\mathrm{ST}}$ values, must be caused by selection against immigrants.

The available evidence suggests that natural selection not only in lichens and wild barley but remarkably across life at 'Evolution Canyon' seems to be the major evolutionary divergence force of biodiversity, of both genotypes and phenotypes.
The setup of 'Evolution Canyon' provides an ideal theatre involving sharp ecological contrasts that have selected decipherable interslope adaptive patterns on a microscale, i.e. within a population subdivided ecologically, during several millions of years. This is the field of microevolution later extending into macroevolutionary patterns. Our future task is to decipher the genetic mystery involved in the wild barley genome and other organisms and highlight evolution in action on a microscale.

\section{Acknowledgements}

This work is supported by the Israeli Ministry of Science, grants nos 1426 and 4147 (with GSF-Forschungszentrum für Umwelt und Gesundheit Gmbh, Neuherberg); the Israeli Discount Bank Chair of Evolutionary Biology, and the Ancell-Teicher Research Foundation for Genetics and Molecular Evolution.

\section{References}

ALlard, R. W., KAHLER, A. L. AND WEIR, B. S. 1972. The effect of selection on esterase allozymes in a barley population. Genetics, 73, 489-503.

APelbaum-ElKaher, I. 1994. Genetic Variation in the Lichen Caloplaca aurantia and in the Wild Barley Hordeum spontaneum in the Nahal-Oren Site, and Detection of Stress Conditions on the Lichen Ramalina duriaei by Physiological Parameters. M.Sc. Thesis, Tel-Aviv University (in Hebrew; English summary).

BROWN, A. H. D., FELDMAN, M. W. AND NEVO, E. 1980. Multilocus structure of natural populations of Hordeum spontaneum. Genetics, 96, 523-536.

ClEGG, M. T., KIDWELL, J. F., KIDWELL, M. G. AND DANIEL, N. J. 1976. Dynamics of correlated genetic systems. I. Selection in the region of the Glued locus of Drosophila melanogaster: Genetics, 83, 793-810.

COTTLE, H. J. 1932. Vegetation on north and south slopes of mountains in S.E. Texas. Ecology, 13, 121-134.

DARWIN, C. 1859. On the Origin of Species by Means of Natural Selection. Murray, London.

Endler, J. A. 1986. Natural Selection in the Wild. Princeton University Press, Princeton, NJ.

GALUN, M. 1970. The Lichens of Israel. The Israeli Academy of Sciences and Humanities, Jerusalem.

GOlenberG, E. M. AND NEvo, E. 1987. Multilocus differentiation and population structure in a selfer, wild emmer wheat, Triticum dicoccoides. Heredity, $\mathbf{5 8}$, $451-456$.

HAMRICK, J. L. AND ALLARD, R. w. 1972. Microgeographical variation in allozyme frequencies in Avena barbata. Proc. Natl. Acad. Sci. U.S.A., 69, 2100-2104.

HAMRICK, J. L. AND HOLDEN, L. R. 1979. Influence of microhabitat heterogeneity on gene frequency distribu- 
tion and gametic phase disequilibrium in Avena barbata. Evolution, 33, 521-533.

HOFFMANN, A. A. AND PARSONS, P. A. 1991. Evolutionary Genetics and Environmental Stress. Oxford University Press, Oxford.

JOHANNESSON, K., JOHANNESSON, B. AND LUNDGREN, u. 1995. Strong natural selection causes microscale allozyme variation in a marine snail. Proc. Natl. Acad. Sci. U.S.A., 92, 2602-2606.

KARLIN, s. 1979. Principles of polymorphisms and epistasis of multilocus systems. Proc. Natl. Acad. Sci. U.S.A., 76, 541-545.

KARLIN, s. 1981. Some natural viability systems for a multiallelic locus: a theoretical study. Genetics, 97, 457-473.

KARLIN, s. 1982. Classifications of selection-migration structures and conditions for a protected polymorphism. Evol. Biol., 14, 61-204.

kimura, M. 1983. The Neutral Theory of Molecular Evolution. Cambridge University Press, Cambridge.

LEVENE, H. 1953. Genetic equilibrium when more than one ecological niche is available. Am. Nat., 87, 311-313.

matTsSon, J. E. AND KARNefelt, I. 1986. Protein banding patterns in the Ramalina siliquosa group. Lichenologist, 18, 231-240.

NEI, M. 1972. Genetic distance between populations. Am. Nat., 106, 283-292.

$\mathrm{NEl}$, M. 1973. Analysis of gene diversity in subdivided populations. Proc. Natl. Acad. Sci. U.S.A., 70, 3321-3323.

NEI, M. 1978. Estimation of average heterozygosity and genetic distance from a small number of individuals. Genetics, 89, 583-590.

NEVO, E. 1978. Genetic variation in natural populations: pattern and theory. Theor. Pop. Biol., 13, 121-177.

NEVO, E. 1988. Genetic diversity in nature: patterns and theory. Evol. Biol., 23, 217-246.

NEVO, E. 1990. Molecular evolutionary genetics of isozymes: patterns, theory and application. In: Ogita, Z.-I. and Markert, C. L. (eds) Isozymes: Structure, Function and Use in Biology and Medicine, pp. 701-742. Wiley-Liss, New York.

NEVO, E. 1992. Origin, evolution, population genetics and resources for breeding of wild barley, Hordeum spontaneum, in the Fertile Crescent. In: Shewry, P. (ed.) Barley: Genetics, Molecular Biology and Biotechnology, pp. 19-43. C.A.B. International, Wallingford, Oxford.

NEVO, E. 1994. Biodiversity: the 'Evolution Canyon' at Nahal Oren, Mt. Carmel, Israel. Isr. J. Bot., 42, 83 (abstract).

NEVO, E. 1995. Asian, African and European biota meet at 'Evolution Canyon', Israel: local tests of global biodiversity and genetic diversity patterns. Proc. R. Soc. B, 262, 149-155.

NEVO, E. 1997. Evolution in action across phylogeny caused by microscale ecological stresses. Theor. Pop. Biol. (in press).

NEVO, E. AND BEILES, A. 1988. Genetic parallelism of protein polymorphism in nature: ecological test of the neutral theory of molecular evolution. Biol. J. Linn. Soc., 35, 229-245.

NEVO, E., SHIMONY, T. AND LIBNI, M. 1977. Thermal selection of allozyme polymorphisms in barnacles. Nature, 267, 699-701.

NEVO, E., ZOHARY, D., BROWN, A. H. D. AND HABER, M. 1979. Genetic diversity and environmental associations of wild barley, Hordeum spontaneum, in Israel. Evolution, 33, 815-833.

NEVO, E., BROWN, A. H. D., ZOHARY, D., STORCH, N. AND BEILES, A. 1981. Microgeographic edaphic differentiation in allozyme polymorphisms of wild barley (Hordeum spontaneum, Poaceae). Pl. Syst. Evol., 138, 287-292.

NeVo, E., BAR-El, C., BEILES, A. AND YOM-TOV, Y. 1982. Adaptive microgeographic differentiation of allozyme polymorphism in landsnails. Genetica, 59, 61-67.

NEVO, E., BEILES, A., STORCH, N., DOLL, H. AND ANDERSEN, B. 1983. Microgeographic edaphic differentiation in hordein polymorphisms of wild barley. Theor. Appl. Genet., 64, 123-132.

NEVO, E., BEILES, A. AND BEN-SHLOMO, R. 1984. The evolutionary significance of genetic diversity: ecological, demographic and life history correlates. Lect. Notes Biomath., 53, 13-213.

NEVO, E., NOY, R., LAVIE, B., BEILES, A. AND MUCHTAR, S. 1986a. Genetic diversity and resistance to marine pollution. Biol. J. Linn. Soc., 29, 139-144.

NeVo, E., BeIles, A., KAPLAN, D., GOlenberG, E. M., OLSVIG-WHITTAKER, L. S. AND NAVEH, z. 1986b. Natural selection of allozyme polymorphisms: a microsite test revealing ecological genetic differentiation in wild barley. Evolution, 40, 13-20.

NEVO, E., Belles, A. AND KRugman, T. 1988a. Natural selection of allozyme polymorphisms. II. A microgeographic climatic differentiation in wild emmer wheat, Triticum dicoccoides. Theor. Appl. Genet., 75, 529-538.

nevo, E., BeIles, A. AND KRUGman, T. 1988b. Natural selection of allozyme polymorphisms. A microgeographic differentiation by edaphic, topographical and temporal factors in wild emmer wheat, Triticum dicoccoides. Theor. Appl. Genet., 76, 737-752.

NEVO, E., NOY-MEIR, I., BEILES, A., KRUGMAN, T. AND AGAM1, M. 1991. Natural selection of allozyme polymorphisms: a micro-geographical spatial and temporal ecological differentiation in wild emmer wheat. Isr. $J$. Bot., 40, 419-449.

NEVO, E., KRugman, T. AND BEILES, A. 1994. Edaphic natural selection of allozyme polymorphisms in Aegilops peregrina at a Galilee microsite in Israel. Heredity, 72, $109-112$.

NEVO, E., BEN-SHLOMO, R., BEILES, A., RONIN, Y., BLUM, S. AND HILLEL, J. 1996. Genomic adaptive strategies: DNA fingerprints reveal ecogenetic parallelism to allozymes, RAPDs, mitochondrial DNA, and chiasma frequency in the actively speciating mole rats in Israel. In: Holmes, R. S, and Lim, H. A. (eds) Gene Families: Structure, Function, Genetics and Evolution, pp. 55-70. World Scientific Publishers, New Jersey. 
OHTA, T. AND TACH1DA, H. 1990. Theoretical study of near neutrality. I. Heterozygosity and rate of mutant substitution. Genetics, 126, 219-229.

OLSVIG-WHITTAKER, L. S., NAVEH, Z., GISKIN, M. AND NEVO, E. 1992. Microsite differentiation in a Mediterranean oak savanna. J. Veget. Sci., 3, 209-216.

PARSONS, P. A. 1994. Habitats, stress, and evolutionary rates. J. Evol. Biol., 7, 387-397.

SHREVE, F. 1922. Conditions indirectly affecting vertical distribution on mountains. Ecology, 3, 269-274.

SIEGEL, 1956. Nonparametric Statistics for the Behavioral Sciences. McGraw-Hill Book Co., New York.

SLATKIN, M. AND BARTON, N. H. 1989. A comparison of three indirect methods for estimating the average level of gene flow. Evolution, 43, 1349-1368.

SOULÉ, M. AND STEWART, B. R. 1970. The niche variation hypothesis: a test and alternatives. Am. Nat., 104,
85-97.

SWOFFORD, D. L. AND SELANDER, R. B. 1989 , BIOSYS-1. $A$ Computer Program for the Analysis of Allelic Variation in Population Genetics and Biochemical Systematics. Release 1.7. D.L. Swofford, Illinois Natural History Survey, Champaign, IL.

UGRINOVSKII, A., KOROL, A. B. AND NEVO, E. 1995. Ecological basis of molecular sequence divergence: Rubisco large subunit gene as an example. German-Israeli Symposium on Computing Science. Aspects of Molecular Biology, 26-28 November, 1995. Tel-Aviv University, Israel.

VAN VALEN, L. 1965. Morphological variation and width of ecological niche. Am. Nat., 99, 377-390.

WRIGHT, s. 1965. The interpretation of population structure by F-statistics with special regard to systems of mating. Evolution, 19, 395-420. 